CCarcinological Society of Japan. doi: 10.18353/crustacea.45.0_69

\title{
Occurrence of the pelagic shrimp Pasiphaea japonica (Decapoda: Pasiphaeidae) in gut contents of demersal predators in a submarine canyon (Toyama Bay, Japan)
}

Nobuaki Nanjo

\begin{abstract}
The purpose of present study is to clarify the predation of P. japonica including larvae by investigating guts of predators caught as a by-catch in the P.japonica fishery. The by-catch, including fish, cephalopods and decapods, were caught once or twice a month between April and November 2008 in a submarine canyon adjacent to the mouth of the Jinzu River in Toyama Bay. Size of the potential predators was measured and the gut contents were identified to the lowest possible taxa. Ostracods, copepods, mysids, cumaceans, amphipods, euphausiids, and decapods were the most common prey in the gut contents of the predators. Pasiphaea japonica, including larvae before metamorphosis, were preyed upon by demersal fishes Crystallichthys matsushimae, Lycodes nakamurae, and Bothrocara hollandi. Occurrence of $P$. japonica in the guts of these predators may be due to the aggregation of larvae in the canyon head which is enclosed by the steeply sloping bottoms and the truncation of the vertical migration of $P$. japonica from the pelagic to the benthopelagic environment.
\end{abstract}

Key words: Pasiphaeidae, shrimp, larva, predation, net feeding, submarine canyon, Toyama Bay

\section{Introduction}

Pasiphaea japonica, a pelagic shrimp of the family Pasiphaeidae, are found in Suruga Bay, Sagami Bay, Enshu-Nada sea region, and Toyama Bay in Japan (Doi, 1990; Hayashi, 2007). The biology of this shrimp has been described in several reports. In Toyama Bay, reproduction of shrimps occurs throughout the year, having a high hatching intensity from October to May, and ovigerous females carry up to 281 eggs (Doi, 1975; Omori, 1976; Nanjo \& Ohtomi, 2009). It is reported that the density of hatched larvae is higher in submarine canyons (Nanjo \& Katayama, 2014).

The shrimps are recognized as a valuable species for fisheries of Toyama Prefecture, being commercially caught by fishing boats using trawl nets in the depths of $40-200 \mathrm{~m}$ in the submarine canyons (Doi, 1975). The annual catch of $P$. japonica was about $600-700 \mathrm{t}$ in 1997-2007, but a tendency of decreasing catch has been observed since 2008, indicating that the stock may be decreasing.

Generally, recruitment of marine species is affected by high mortality in the early life stages, and varies due to starvation, transport, or predation (Hjort, 1914; Cushing, 1978; Houde, 1987; Nakata, 1991). It is reported that larval stages of crustaceans also play a role in recruitment fluctuations to the stock (e.g. DeLancey et al., 1994; Kodama et al., 2003). Nanjo and Konishi (2009) described that larvae of P. japonica metamorphosed at 12 days after hatching with no food items under $13^{\circ} \mathrm{C}$, indicating that larvae have a high starvation tolerance by consuming endogenous nutrition stored from the yolk. Larvae of $P$. japonica aggregate around submarine canyon heads without being transported offshore where food resources are 
poorer (Nanjo \& Katayama, 2014). Accordingly, it is thought that starvation and dispersal offshore are not direct causes of larval mortality. On the other hand, Minello et al. (1989) described that predation is a direct cause of larval mortality of crustaceans.

Predation of $P$. japonica was reported by Uchiyama (1999), indicating that the semi-pelagic fish Theragra chalcogramma, caught by bottom gill nets, mainly fed on $P$. japonica. In other studies, it has been reported that $\mathrm{Pa}$ siphaea sivado and Pasiphaea multidentata, which are allied species to P. japonica, are preyed upon by the fishes Lampanyctus macdonaldi (Myctophidae) in the east Greenland Sea, Lampanyctus crocodilus (Myctophidae) in the western Mediterranean Sea, Lycodes frigidus (Zoarcidae), and Paraliparis bathybius (Liparidae) in the eastern Norwegian Sea (Stefanescu \& Cartes, 1992; Bjelland et al., 2000; Klimpel et al., 2006), squids Illex coindetii and Todarodes sagittatus (Ommastrephidae) in the northwestern Mediterranean Sea (Rosas-Luis et al., 2014), and shrimps Plesionika edwardsi, Plesionika martia, and Plesionika acanthonotus (Pandalidae) in the western Mediterranean Sea (Cartes, 1993). There are, however, only a few reports on the occurrence of caridean larvae or juveniles in the gut contents of predators (e.g. Young \& Davis, 1992; Beyst et al., 1999).

The purpose of present study is to clarify the predation of $P$. japonica including larvae by investigating the gut contens of fish, squid, and shrimp caught as by-catch in the $P$. japonica fishery, since it was reported in previous studies that these predators feed on shrimp species allied to $P$. japonica. This information could be helpful for analyzing of the stock of $P$. japonica.

\section{$\square$ Materials and Methods}

The fishing season for P. japonica runs from April to November under the regulations for the fishery. Possible predators caught as by-
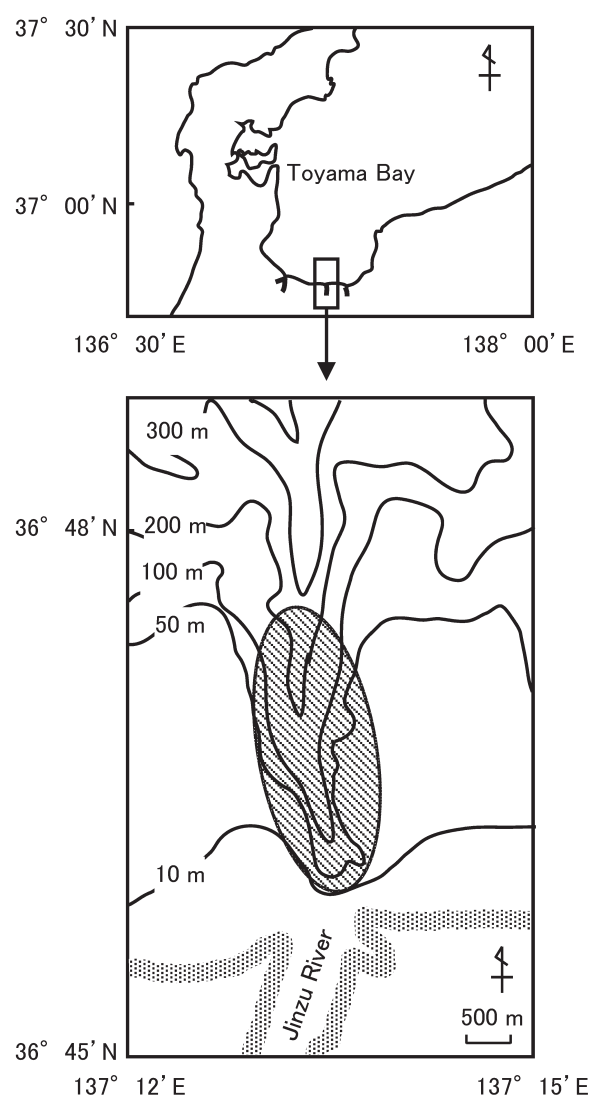

Fig. 1. Fishing grounds where the specimens were collected in the present study (shaded area).

catch during commercial fishing aimed at $P$. japonica, which runs throughout the morning, in the submarine canyon adjacent to the mouth of Jinzu River in Toyama Bay were examined once or twice a month in the fishing season of 2008 (Fig. 1). The specimens were kept cold (approximately $1-2^{\circ} \mathrm{C}$ ) and taken to the laboratory. In the laboratory, the sizes of the specimens, i.e., total length (TL) and fork length in fishes, mantle length in cephalopods, or carapace length $(\mathrm{CL})$ in decapods, were measured with a digital slide caliper (Mitutoyo Corp. Digimatic Caliper), and then the guts were eviscerated, and the contents were identified to the lowest possible taxa under a stereoscopic microscope (approximately 10-40 x magnification; Olympus SZH).

Data on the gut contents of specimens were 
expressed as the percent frequency of occurrence $(F \%)$ :

$$
F \%{ }_{i}=m_{i} \cdot 100 / M
$$

where $m_{i}$ is the number of specimens that fed on the prey taxon $i$, and $M$ is the total number of specimens examined, excluding specimens without food in the gut. Carapace length from the tip of the rostral spine to the medial posterior margin of the carapace of $P$. japonica that occurred in the guts was also measured with a digital slide caliper or a micrometer under a stereoscopic microscope.

It is reported that feeding activities within the trawl nets by fishes (termed as "net feeding”) could cause bias problems for dietary studies (Lancraft \& Robison, 1980; Buckel et al., 1998). Therefore, in the present study, $P$. japonica caught by fishing boats were also sampled on the same days when the by-catch species were collected to estimate the minimum size of $P$. japonica caught by trawl nets. In the laboratory, 200 individuals were chosen randomly and the CL was measured with a digital slide caliper, indicating that the minimum size of $P$. japonica captured in the fishing trawl nets was $6.8 \mathrm{~mm} \mathrm{CL}$.

\section{Results}

Specimens caught as the by-catch included 12 species of fishes, 3 cephalopods, and 3 decapods from April to November (Table 1). The number of specimens ranged between 1 and 24 individuals for each species. Frequency of the specimens without food in the guts ranged from 0 to 75.0 in fishes, 0 to 72.2 in cephalopods, and 37.5 to 66.7 in decapods, excluding Tanakius kitaharai and Watasenia scintillans with no food in the guts (Table 2). Crustaceans were fed on by most of the bycatch specimens, and fishes, mollusks, and polychaetes were also found in the guts of some specimens. Crustaceans found in the guts of the specimens were mainly ostracods, cope- pods, mysids, cumaceans, amphipods, euphausiids, and decapods (Table 3). The number of $P$. japonica, including larvae before metamorphosis, in the guts of predators was 20 individuals, which were fed on by the fishes $C$. matsushimae, A. lineatus, L. nakamurae, B. hollandi, and T. japonicus, and the cephalopod B. magister. The gut contents of fishes were easy to identify $P$. japonica due to feeding on without chewing. On the other hand, $P$. japonica that occurred in the guts of $B$. magister were identified from the shapes of mandibles, eyes, and eggs, which were carried by females (Fig. 2). These species also fed on mysids, copepods, amphipods, and cumaceans, excluding $T$. japonicus and $B$. magister which fed only on $P$. japonica.

Figure 3 shows the frequency of CLs of $P$. japonica caught by commercial fishing boats on the same days when specimens were sampled, and the relationship between TLs of the by-catch specimens and CLs of P. japonica that occurred in the guts of the specimens. The CLs of the measured $P$. japonica occurred in the by-catch specimen guts ranged from 1.7 to $17.2 \mathrm{~mm}$. The size of the partially digested larvae was assumed to be $1.6 \mathrm{~mm} \mathrm{CL}$, based on the size described by Nanjo and Konishi (2009), since these larvae were judged larval stage 1 or 2 from the morphological characters. The average size of $P$. japonica caught by fishing boats was $18.3 \mathrm{~mm} \mathrm{CL} \pm 2.5(\mathrm{SD})$, which was larger than the size of $P$. japonica that occurred in the guts of predators. The TL range of the by-catch specimens that fed on P.japonica, with CLs less than the minimum size of shrimp caught by the commercial trawl nets, was between 79.0 and $171.0 \mathrm{~mm}$ for L. nakamurae, $227.0 \mathrm{~mm}$ for $B$. hollandi, and $64.4 \mathrm{~mm}$ for $C$. matsushimae, from May to September. On the other hand, $P$. japonica with CLs more than the minimum commercial size of shrimp were fed on by L. nakamurae, with sizes of 110.8 and $204.0 \mathrm{~mm}$, and by T.japonicus, with sizes between 371.0 and $406.0 \mathrm{~mm}$, from June 


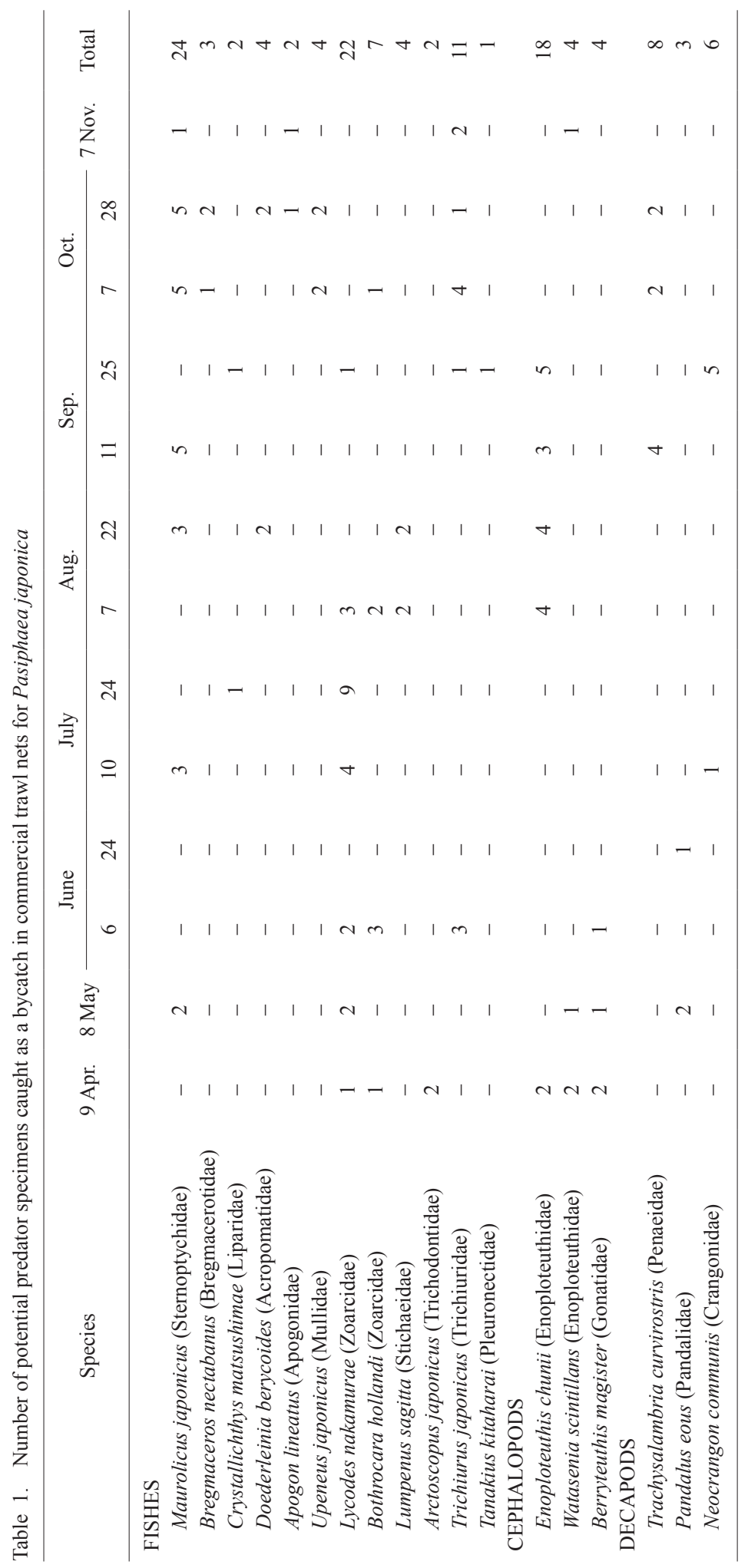


Table 2. Frequency of prey items that occurred in the guts of specimens

\begin{tabular}{|c|c|c|c|c|c|c|c|c|}
\hline Species & $\mathrm{N}$ & $\begin{array}{l}\text { No food } \\
\text { in guts }\end{array}$ & Fishes & Mollusks & Crustaceans & Polychaetes & Others & Unknown \\
\hline \multicolumn{9}{|l|}{ FISHES } \\
\hline Maurolicus japonicus & 24 & 58.3 & 10.0 & - & 60.0 & - & - & 30.0 \\
\hline Bregmaceros nectabanus & 3 & 33.3 & - & - & 100.0 & - & - & - \\
\hline Crystallichthys matsushimae & 2 & - & - & - & 100.0 & - & 50.0 & - \\
\hline Doederleinia berycoides & 4 & - & - & - & 100.0 & 25.0 & - & - \\
\hline Apogon lineatus & 2 & - & - & - & 100.0 & - & - & - \\
\hline Upeneus japonicus & 4 & 75.0 & - & - & - & - & 100.0 & - \\
\hline Lycodes nakamurae & 22 & - & 4.5 & 9.1 & 95.5 & 18.2 & 27.3 & 18.2 \\
\hline Bothrocara hollandi & 7 & - & - & - & 100.0 & - & - & - \\
\hline Lumpenus sagitta & 4 & - & 50.0 & 75.0 & 100.0 & 75.0 & 25.0 & - \\
\hline Arctoscopus japonicus & 2 & - & - & - & 100.0 & - & - & - \\
\hline Trichiurus japonicus & 11 & - & 45.5 & - & 54.5 & - & 9.1 & 9.1 \\
\hline Tanakius kitaharai & 1 & 100.0 & - & - & - & - & - & - \\
\hline \multicolumn{9}{|l|}{ CEPHALOPODS } \\
\hline Enoploteuthis chunii & 18 & 72.2 & - & - & 40.0 & - & 60.0 & - \\
\hline Watasenia scintillans & 4 & 100.0 & - & - & - & - & - & - \\
\hline Berryteuthis magister & 4 & - & - & - & 100.0 & - & 25.0 & - \\
\hline \multicolumn{9}{|l|}{ DECAPODS } \\
\hline Trachysalambria curvirostris & 8 & 37.5 & - & - & 100.0 & - & - & - \\
\hline Pandalus eous & 3 & 66.7 & 100.0 & - & 100.0 & - & - & - \\
\hline Neocrangon communis & 6 & 50.0 & - & - & - & - & 33.3 & 66.7 \\
\hline
\end{tabular}

to July.

\section{$\square$ Discussion}

Among the by-catch specimens, $P$. japonica were found in the guts of $C$. matsushimae, $A$. lineatus, L. nakamurae, B. hollandi, T. japonicus and B. magister. Although these species fed on $P$. japonica of various sizes, some shrimps might have been fed on during net feeding. Assuming that the minimum CL of the shrimp caught by trawl nets is the threshold of the shrimp exposed to net feeding, it was possible that the occurrence of 2 shrimps in the guts of L. nakamurae and 3 shrimps in T. japonicus were due to net feeding.

Larvae of $P$. japonica were identified in the guts of L. nakamurae on some sampling days. Lycodes nakamurae belongs the family Zoarcidae, which is known as one of demersal fishes caught by trawl nets (Møller \& Jørgensen, 2000; Okiyama, 2004; Balanov \& Solomatov, 2008). In the present study, L. nakamurae fed also on mysids and cumaceans, which are typically benthic crustaceans, since it is reported that mysids living near the sea bottom are dominant in the fishing grounds of $P$. japonica (Nanjo, 2007) and cumaceans are mainly benthic (Gamo, 1997). On the other hand, larvae of $P$. japonica that occurred in the guts of demersal fishes are mainly pelagic, occurring in depths of 100-150 m, with no difference in the range of vertical distribution between daytime and nighttime (Nanjo \& Katayama, 2014). Mauchline and Gordon (1991) suggested a truncation of the vertical distribution or impingement of the horizontal movement of pelagic species enabled predation of pelagic organisms by benthopelagic predators. It is thought that both of the larval truncation and impingement hardly occur due to a narrow range of the vertical distribution and horizontal movement in larval stages. Larvae of $P$. japon$i c a$, however, may reach the benthic boundary layer, since the larval distribution aggregates in the canyon head enclosed by the steeply slop- 


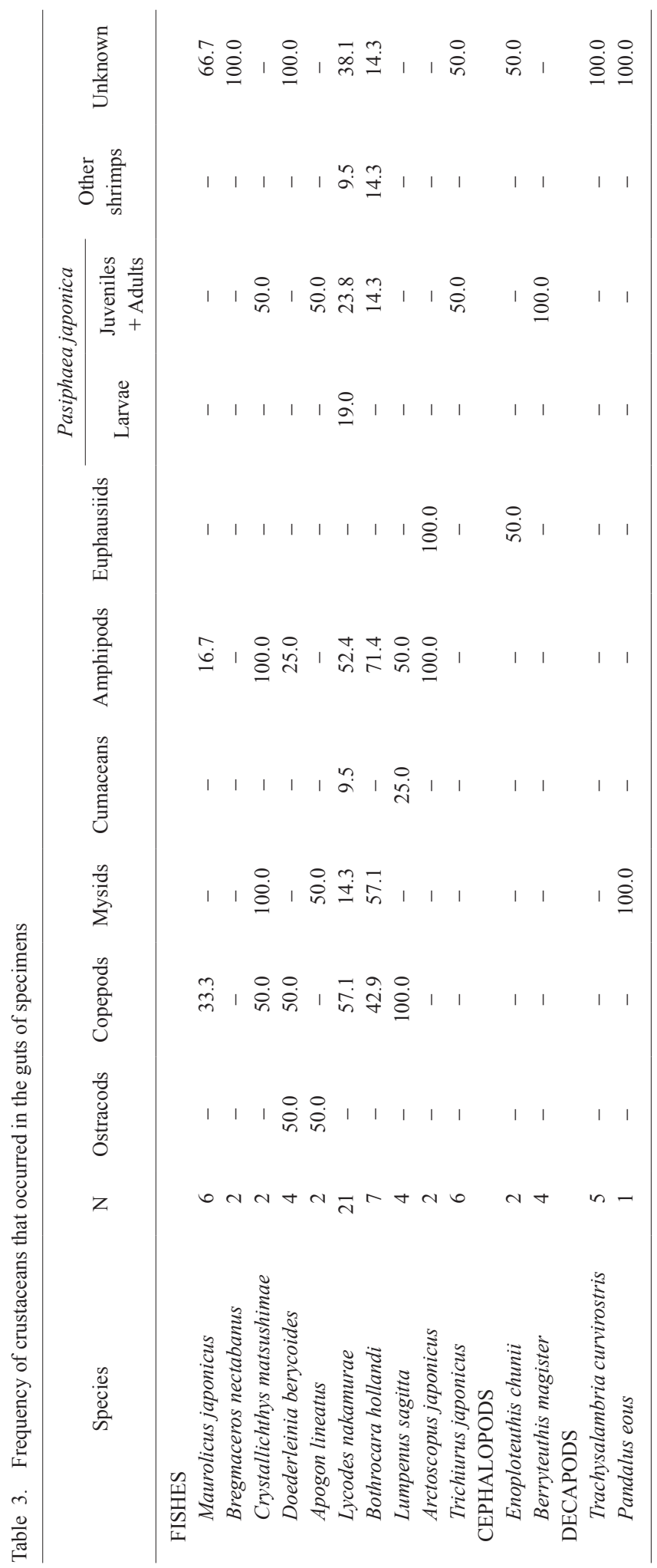


ing bottoms (Nanjo \& Katayama, 2014). It is also reported that zooplankton are transported towards the coast by currents within submarine canyons (e.g. Allen et al., 2001).

The sizes of some $P$. japonica, excluding larval stages, that occurred in the guts of $C$. mat-

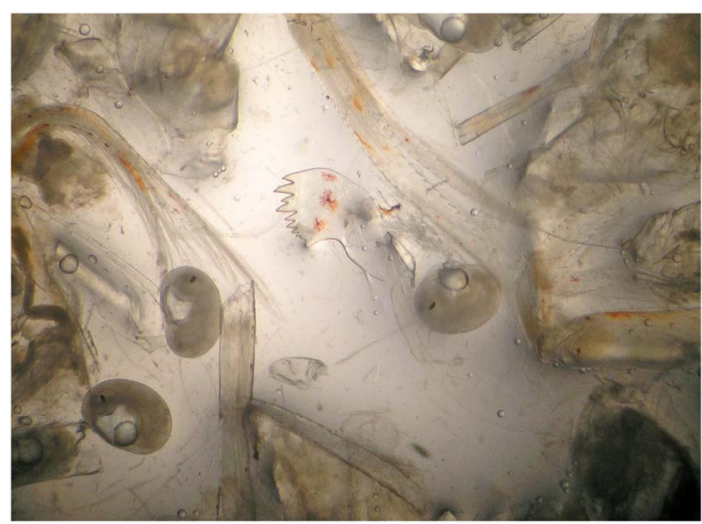

Fig. 2. A photograph showing a mandible and eggs of Pasiphaea japonica that occurred in the guts of Berryteuthis magister. sushimae, L. nakamurae, and B. hollandi are similar to the sizes reported by Nanjo \& Katayama (2014), which these shrimps migrate down to the depth of about $200 \mathrm{~m}$ in the daytime (weighted mean depths of 171.3$227.3 \mathrm{~m}$ ). Crystallichthys matsushimae and $B$. hollandi are also demersal fishes like L. nakamurae (Okiyama, 2004). Accordingly, it is thought that the occurrence of $P$. japonica after larval stages in the guts of these fishes is caused by the truncation of vertical migration as described by Mauchline \& Gordon (1991), since the depth range of the fishing grounds, where these demersal fishes were caught by commercial fishing boats, is similar or shallower than the lower limit of vertical distribution (Doi, 1975).

The present study firstly examined predators feeding larvae of $P$. japonica. Although only a small number of larvae were observed in the guts of fishes, occurrence during sampling days

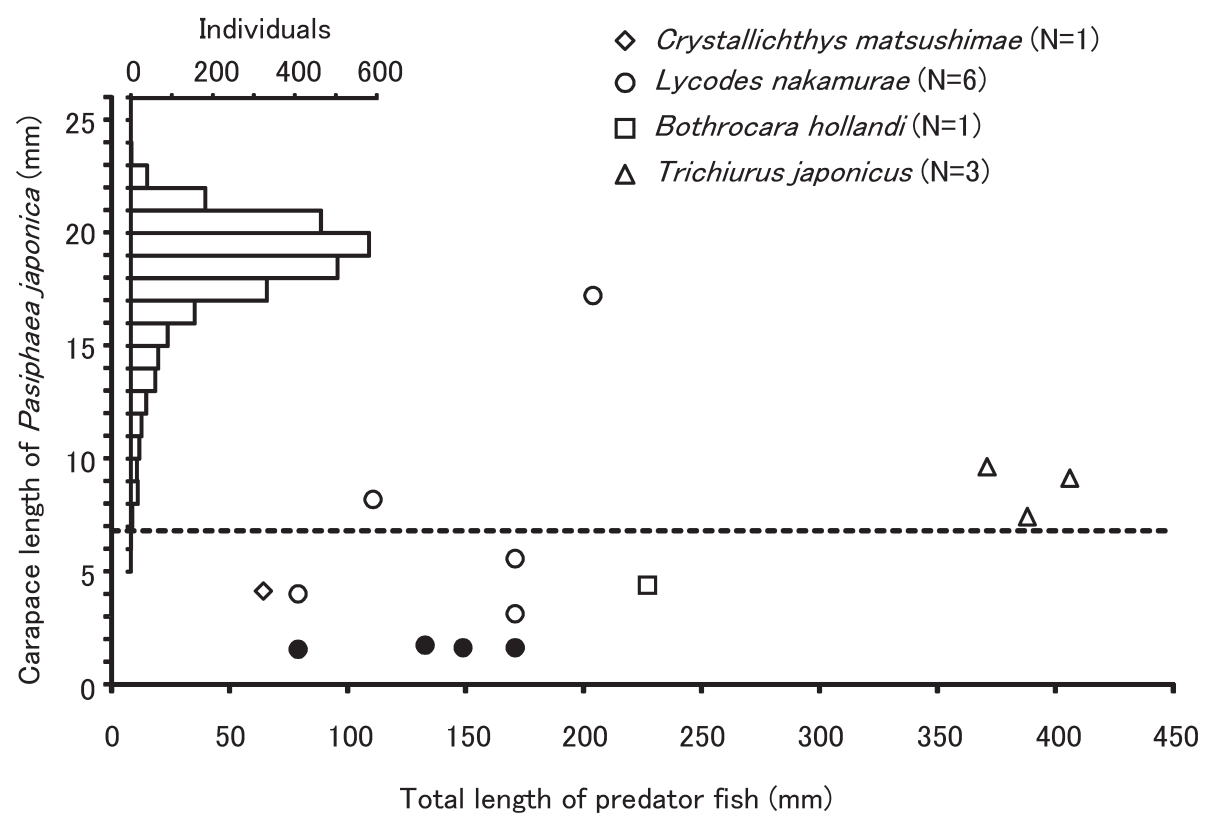

Fig. 3. Frequency of carapace length of Pasiphaea japonica caught by fishing boats in the present study (left upper) and relationship between total length of predator fishes and carapace lengths of $P$. japonica that occurred in the guts of specimens, excluding specimens that fed on P. japonica that were partially digested and therefore having an unknown CL. Solid circles show Lycodes nakamurae that fed on $P$. japonica larvae. Dotted line is the minimum size $(6.8 \mathrm{~mm})$ of carapace length of $P$. japonica caught by fishing nets in the present study. 
is a significant result, indicating that demersal fishes should be also investigated to explain the fluctuations in stocks of $P$. japonica as a potential predator.

\section{Acknowledgements}

I express members of the Toyama Prefectural Agricultural, Forestry and Fisheries Research Center Fisheries Research Institute for helpful comments on this paper. I am grateful to the staff of the Toyama city fisheries co-operative association for samplings. I also thank reviewers who helped with revision of the manuscript.

\section{Literature Cited}

Allen, S. E., Vindeirinho, C., Thomson, R. E., Foreman, M. G. G., \& Mackas, D. L., 2001. Physical and biological processes over a submarine canyon during an upwelling event. Canadian Journal of Fisheries and Aquatic Sciences, 58: 671-684.

Balanov, A. A., \& Solomatov, S. F., 2008. Species composition and distribution of Zoarcidae in the northern part of the Sea of Japan from the data of trawl surveys. Journal of Ichthyology, 48: 14-28.

Beyst, B., Cattrijsse, A., \& Mees, J., 1999. Feeding ecology of juvenile flatfishes of the surf zone of a sandy beach. Journal of Fish Biology, 55: 1171-1186.

Bjelland, O., Bergstad, O. A., Skjæraasen, J. E., \& Meland, K., 2000. Trophic ecology of deep-water fishes associated with the continental slope of the eastern Norwegian Sea. Sarsia, 85: 101-117.

Buckel, J. A., Fogarty, M. J., \& Conover, D. O., 1998. Foraging habits of bluefish, Pomatomus saltatrix, on the U. S. east coast continental shelf. Fishery Bulletin, 97: 758-775.

Cartes, J. E., 1993. Diets of deep-water pandalid shrimps on the Western Mediterranean slope. Marine Ecology Progress Series, 96: 49-61.

Cushing, D. H., 1978. Biological effects of cli- mate change. Rapports et Procès-verbaux des Réunions du Conseil Permanent International pour l'Exploration de la Mer, 173: 107-116.

DeLancey, L. B., Jenkins, J. E., \& Whitaker, J. D., 1994. Results of long-term, seasonal sampling for Penaeus postlarvae at Breach Inlet, South Carolina. Fishery Bulletin, 92: 633640.

Doi, S., 1975. Notes on Pasiphaea sp. in Toyama Bay. Japan Sea Regional Fisheries Research News, 285: 1-5. (In Japanese)

Doi, S., 1990. On the distribution of Japanese glass shrimp, Pasiphaea japonica in Toyama Bay, the Japan Sea. Bulletin of Toyama Prefectural Fisheries Experiment Station, 2: 2731. (In Japanese)

Gamo, S, 1997. Order Cumacea. In: M. Chihara \& M. Murano, (eds.), An Illustrated Guide to Marine Plankton in Japan, Tokai University Press, Tokyo, 1085-1111. (In Japanese)

Hayashi, K., 2007. Caridean shrimps (Crustacea: Decapoda: Pleocyemata) from Japanese waters, part 1: Oplophoroidea, Nematocarcinoidea, Atyoidea, Stylodactyloidea, Pasiphaeoidea and Psalidopodoidea. 292 pp., Seibutsu Kenkyusha, Tokyo. (In Japanese)

Hjort, J., 1914. Fluctuations in the great fisheries of northern Europe, viewed in the light of biological research. Rapports et Procèsverbaux des Réunions du Conseil Permanent International pour l'Exploration de la Mer, 20: $1-228$

Houde, E. D., 1987. Fish early life dynamics and recruitment variability. American Fisheries Society Symposium Series, 2: 17-29.

Klimpel, S., Palm, H. W., Busch, M. W., Kellermanns, E., \& Rückert S., 2006. Fish parasites in the Arctic deep-sea: Poor diversity in pelagic fish species vs. heavy parasite load in a demersal fish. Deep-Sea Research Part I, 53: 1167-1181.

Kodama, K., Shimizu, T., \& Aoki, I., 2003. Possible factors causing the fluctuation of the recruitment of Japanese mantis shrimp Oratosquilla oratoria in Tokyo Bay. Bulletin of 
the Kanagawa Prefectural, Fisheries Research Institute, 8: 71-76. (In Japanese)

Lancraft, T. M., \& Robison, B. H., 1980. Evidence of postcapture ingestion by midwater fishes in trawl nets. Fishery Bulletin, 77: 713-715.

Mauchline, J., \& Gordon, J. D. M., 1991. Oceanic pelagic prey of benthopelagic fish in the benthic boundary layer of a marginal oceanic region. Marine Ecology Progress Series, 74: 109-115.

Minello, T. J., Zimmerman, R. J., \& Martinez, E. X., 1989. Mortality of young brown shrimp Penaeus aztecus in estuarine nurseries. Transactions of the American Fisheries Society, 118: 693-708.

Møller, P. R., \& Jørgensen, O. A., 2000. Distribution and abundance of eelpouts (Pisces, Zoarcidae) off West Greenland. Sarsia, 85: 2348.

Nakata, H., 1991. Coastal processes related to the transport, survival and recruitment of fish larvae. Bulletin on Coastal Oceanography, 28: 195-220. (In Japanese)

Nanjo, N., 2007. Feeding habits of the glass shrimp Pasiphaea japonica in Toyama Bay of the Sea of Japan. Crustacean Research, 36: 45-51.

Nanjo, N., \& Konishi, K., 2009. Complete larval development of the Japanese glass shrimp Pasiphaea japonica Omori, 1976 (Decapoda: Pasiphaeidae) under laboratory conditions. Crustacean Research, 38: 77-89.

Nanjo, N., \& Ohtomi, J., 2009. Reproductive biology of Pasiphaea japonica females in Toyama Bay, central Japan. Fisheries Science, 75: 1189-1195.

Nanjo, N., \& Katayama, S., 2014. Distribution of Pasiphaea japonica larvae in submarine canyons and adjacent continental slope areas in Toyama Bay, Sea of Japan. Journal of Marine Systems, 137: 28-34.

Okiyama, M., 2004. Deepest demersal fish community in the Sea of Japan: A review. Con- tributions from the Biological Laboratory, Kyoto University, 29: 409-429.

Omori, 1976. The glass shrimp, Pasiphaea japonica sp. nov. (Caridea, Pasiphaeidae), a sibling species of Pasiphaea sivado, with notes on its biology and fishery in Toyama Bay, Japan. Bulletin of the National Science Museum, Series A (Zoology), 2: 249-266.

Rosas-Luis, R., Villanueva, R., \& Sánchez, P., 2014. Trophic habits of the ommastrephid squid Illex coindetii and Todarodes sagittatus in the northwestern Mediterranean Sea. Fisheries Research, 152: 21-28.

Stefanescu, C., \& Cartes, J., 1992. Benthopelagic habits of adult specimens of Lampanyctus crocodilus (Risso, 1810) (Osteichthyes, Myctophidae) in the western Mediterranean deep slope. Scientia Marina, 56: 69-74.

Uchiyama, I., 1999. Composition of stomach content of walleye pollack, Theragra chalcogramma, in Toyama Bay. Bulletin of Toyama Prefectural Fisheries Research Institute, 11: 9-18. (In Japanese)

Young, J. W., \& Davis, T. L. O., 1992. Feeding ecology and interannual variations in diet of larval jack mackerel, Trachurus declivis (Pisces: Carangidae), from coastal waters of eastern Tasmania. Marine Biology, 113: 1120.

\section{Address}

(NN) Toyama Prefectural Agricultural, Forestry and Fisheries Research Center Fisheries Research Institute, 364 Takatsuka, Namerikawa, Toyama 936-8536, Japan.

\section{E-mail addresses}

(NN) glshrimp@gmail.com; nobuaki.nanjo@ pref.toyama.lg.jp 